\title{
Factors Affecting Profit Growth with Firm Size as a Moderating Variable (Study in Food and Beverage Companies Listed on the Indonesia Stock Exchange)
}

\author{
Weni Rosali ${ }^{1)^{*}}$, Iskandar Muda ${ }^{2)}$, Keulana Erwin ${ }^{3)}$ \\ ${ }^{1), 2), 3)}$ Departement of Accounting, Faculty of Economics and Business, Universitas Sumatera Utara, Medan, Indonesia
}

\begin{abstract}
This study aimed to determine the effect of the Current Ratio, Debt to Asset Ratio, Inventory Turnover, and Sales Growth on Profit Growth with Firm Size as a moderating variable. This research population is all food $\&$ beverage companies listed on the Stock Exchange from 2009 - 2019. The sampling technique uses purposive sampling so that the selected sample is ten companies. The data analysis method in this research uses the panel data method. The results showed that: (1) Current Ratio had a negative and significant effect on Profit Growth, (2) Debt to Asset Ratio had a negative and significant impact on Profit Growth, (3) Inventory Turnover had a positive and not significant effect on Profit Growth, (4) Sales Growth has a positive and insignificant impact on Profit Growth, (5) Firm Size as a moderating variable can strengthen and significant the relationship of Debt to Asset Ratio to Profit Growth, but Firm Size is not able to moderate the effect of Current Ratio, Inventory Turnover, and Sales Growth on Profit Growth on food and beverage companies listed on the Indonesia Stock Exchange in 2009-2019
\end{abstract}

Keyword:- Current Ratio, Debt to Asset Ratio, Inventory Turnover, Sales Growth, Profit Growth, Firm Size.

\section{INTRODUCTION}

Businesses in the world can categorize into two parts, which are profit-oriented and nonprofit oriented. Regardless of profit-oriented motives or social welfare motives, financial performance is the primary key in organizations to achieve their goals. Information about financial performance will shape decisions regarding the organization's future. That is why accounting has evolved to meet the financial information needs of business organizations worldwide, providing information about financial performance to enable better decision making. Financial ratios can call accounting tools that will help various decision-makers make decisions regarding the company's economic performance.

According to Subramanyam (2017), the most widely requested part of corporate information by the financial market is profit. Profit is the most crucial parameter of a company's economic performance. Benefit aims to measure changes in shareholder wealth during one period and estimate the company's current profitability, i.e., the extent to which the company can cover operating costs and obtain returns for shareholders. Information about earnings becomes very important because gains can help estimate the company's future profit potential.

Earnings growth is the increase or decrease in corporate profits per year. Where, if the company's profit growth is high, so the company's dividend distribution increases. Therefore, profit growth can affect the decisions of investors who will invest their capital in the company.

The Ministry of Industry noted, throughout, 2018 the food and beverage industry could grow by $7.91 \%$ or exceed the national economic growth at $5.17 \%$. The growth of large and medium manufacturing industry production in quarter IV-2018 increased by $3.90 \%$ (yon-y) compared to quarter IV-2017, which was caused by the increase in beverage industry production, which reached $23.44 \%$. Furthermore, the food industry is one of the sectors that support the increase in national investment value, which in 2018 contributed up to $\mathrm{Rp} 56.60$ trillion. The realization of the total investment value in the manufacturing industry sector last year reached Rp 222.3 trillion. "In 2018, the manufacturing industry sector's workforce reached 18.25 million people, an increase of $17.4 \%$ compared to 2015 . The food industry became the largest contributor to $26.67 \%$," he said. The Minister of Industry added Indonesian food and beverage products have known to have competitiveness in the global arena through various types. It marked by achieving an export value of USD 29.91 billion in 2018 (Kemenperin. (2019).

The food and beverage industry is one of the leading sectors of the Indonesian manufacturing sector. The high value of the food and beverage industry causes this sector to contribute to GDP from Indonesia (Mahardhika, 2018).

Earnings growth can be influenced internally through changes in the components of financial statements, such as changes in sales, cost of goods sold, operating expenses, and others.. Inconsistent profit growth in food and beverage sector companies from year to year, compared to the potential and considerable growth opportunities in Indonesia, is a phenomenon underlying the study of profit growth in food and beverage sector companies.

Based on the description of the phenomenon above, the writer tries to analyze the effect of the Current Ratio, Debt to Asset Ratio, Inventory Turnover, and Sales Growth with Firm Size as a moderating variable on Profit Growth. 


\section{LITERATURE REVIEW}

\section{A. Agency Theory}

Agency theory states that modern companies owned by shareholders but run by managers, and both have different economic interests. Shareholders as principals own the company and want their wealth to remain sustainable and increase; this means that they wish to sustainable and growing profits. While managers as agents, who are assumed to take actions and make financial decisions to maximize shareholder wealth, also desire to have a high standard of living financed by high salaries and benefits. It can lead to a conflict of interest or the so-called agency problem that can inhibit profits and cost the principal who hires the agent (Donleavy, 2016).

\section{B. Financial Ratio Analysis}

According to Kasmir (2015), "financial ratios are the activities of comparing numbers in a financial report by dividing one number with another number." Based on the description, it can conclude that the analysis of financial statements is "a way of analysis using comparative calculations of quantitative data shown in the form of a balance sheet or profit and loss." Financial ratios categorized into the following 6 (six) groups: Liquidity Ratio, Leverage Ratio, Activity Ratio, Profitability Ratio, Growth Ratio, \& Valuation Ratio.

\section{Profit Growth}

Profit in financial terms summarizes the net results of the company's business operations during a specific period. Conceptually, benefit aims to measure changes in shareholder wealth over a period and estimate the current profitability of a business, i.e., the extent to which the industry can cover operating costs and obtain returns for its shareholders (Subramanyam, 2017).

\section{Current Ratio}

According to Hery (2017), Current Ratio (CR) is a ratio used to measure a company's ability to meet its shortterm liabilities due soon by using the total available current assets. For companies in general, the problem of efficiency in using capital is more important than the issue of profit, because huge benefits are not the only measure that the company has been able to work efficiently.

\section{E. Debt to Asset Ratio}

According to Hery (2017), Debt to Asset Ratio is a ratio used to measure total debt ratio to total assets. Companies with a high Debt to Asset Ratio indicate that most of the company's assets financed by debt. The higher the debt can have an impact on the emergence of significant financial risk, namely (1) the higher chance that the company will not be able to pay off its debt with its assets; (2) the higher the interest expense that must be borne by the company. However, if the debt can use efficiently and effectively to buy productive assets (such as machinery and equipment), or finance business expansion, it will allow the company to get a significant profit.

\section{F. Inventory Turnover}

Inventory Turnover is a ratio used to measure the number of times the funds embedded in a revolving inventory in a period, or how long (in days) the average stock is stored in a warehouse until it finally sold. The higher Inventory Turnover shows the working capital embedded in merchandise inventory is getting smaller. It means that merchandise inventory can trade so that the funds embedded in the stock not too long used as cash. The higher this ratio, the more liquid the company's list (Hery, 2017).

\section{G. Sales Growth}

Sales growth reflects the success of investment in the past period and can be used to predict future growth. Sales growth is an indicator of the demand and competitiveness of companies in an industry. The growth rate will affect the company's ability to sustain profits to fund future opportunities (Barton, L., Ned C. Hill, \& Sundaran, 1989). Companies that experience an increase in sales level from one period to the next, supported by effective sales management, can increase profits (Rice, 2016).

\section{H. Firm Size}

The size of the company provides information on how big the total assets owned by a company. The total assets owned by a company describe the capital and liabilities they have. Firm Size influences the profits of a company. The higher the size of a company, the more the funds managed are also significant, and the management is also increasingly complex. The size of a company will undoubtedly affect its ability to bear the risks that may occur due to various situations that it faces. Large companies have a better ability to deal with threats and develop company operations than small companies. Companies with significant assets will undoubtedly attract the attention of many people, both the public and investors. It makes the company more careful and still maintains stability in financial reporting (Margareth, 2016).

\section{Framework}

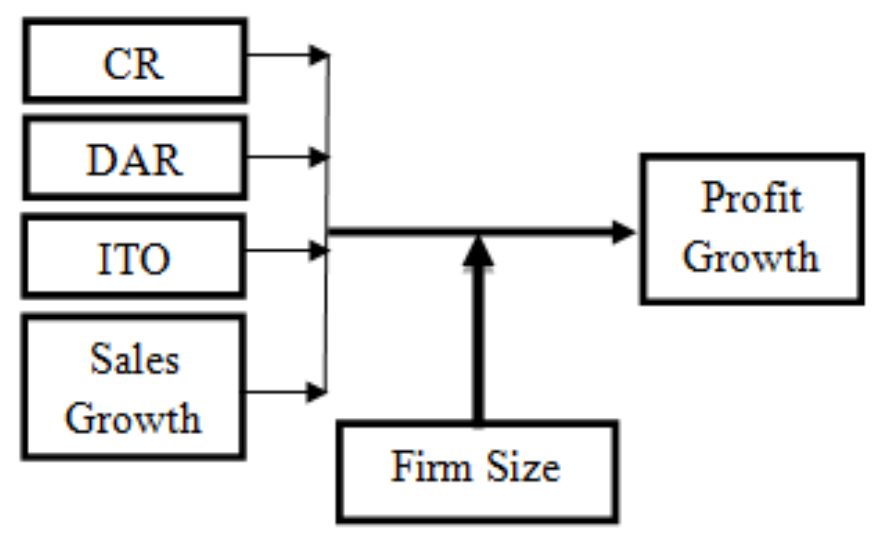

Fig 1 
J. Hypothesis

H1: CR has a negative effect on Profit Growth.

H2: DAR has a negative effect on Profit Growth.

H3: ITO has a positive effect on Profit Growth.

H4: Sales Growth has a positive effect on Profit Growth.

H5: Company size can moderate Current Ratio, Debt to Asset Ratio, Inventory Turnover, and Sales Growth to Profit Growth

\section{RESEARCH METHODOLOGY}

\section{A. Research Approach}

This type of research uses the causal research method. According to Erlina (2011), "causal research aims to test hypotheses and explain phenomena in the form of relationships between variables." In this research, we will see Financial Ratios' effect on Firm Profit Growth with Firm Size as a Moderating Variable (Study of Food and Beverage Companies Listed on the Indonesia Stock Exchange).

\section{B. Data Analysis Methods}

The data analysis method in this research uses the panel data method. According to Satria (2018), panel data combines cross-section data and time-series data. There are three methods in estimating the regression model with panel data, namely the Ordinary Least Square (OLS), Fixed Effect (FE), and Random Effect (RE) methods. The data in this study will process with the STATA 16 application.

\section{RESULT}

\section{A. Research result}

In this research, regression analysis used to determine whether there is an influence of independent variables, namely current ratio, debt to asset ratio, inventory turnover, $\&$ sales growth on the dependent variable, which is profit growth with firm size as a moderating variable.

\begin{tabular}{|c|c|c|c|}
\hline \multirow[t]{5}{*}{ Linear regression } & Number of obs & $=$ & 110 \\
\hline & $F(4,105)$ & $=$ & 5.22 \\
\hline & Prob $>F$ & $=$ & 0.0007 \\
\hline & R-squared & $=$ & 0.3442 \\
\hline & Root MSE & $=$ & .85406 \\
\hline
\end{tabular}

\begin{tabular}{|c|c|c|c|c|c|c|}
\hline profitgrowth & Coef. & $\begin{array}{l}\text { Robust } \\
\text { Std. Err. }\end{array}$ & $t$ & $P>|t|$ & [ $95 \%$ Conf. & Interval] \\
\hline $\mathrm{cr}$ & -.2815267 & 1019002 & -2.76 & 0.007 & -.483576 & -.0794773 \\
\hline dar & -3.908605 & 1.134355 & -3.45 & 0.001 & -6.157822 & -1.659389 \\
\hline ito & .0472133 & .0396954 & 1.19 & 0.237 & -.0314953 & .1259219 \\
\hline salesgrowth & .0452395 & .0675289 & 0.67 & 0.504 & -.088658 & 1791369 \\
\hline _cons & 2.454995 & .875224 & 2.80 & 0.006 & .719588 & 4.190403 \\
\hline
\end{tabular}

Table 1:- Results of Regression Analysis

\section{B. Partial Significance Test (Statistical Test $-t$ )}

Based on Table 1, it knows that the regression coefficient value of the Current Ratio variable is -0.28 and the Prob value. It is 0.007 , which is < significance level of 0.05 , the regression coefficient value of the Debt to Asset Ratio variable is -3.91 and the Prob value. It is 0.001 , which is $<$ the significance level of 0.05 , the regression coefficient value of the Inventory Turnover variable is 0.05 , and the value of Prob. It is 0.237 , the regression coefficient value of the Sales Growth variable is 0.05 , and Prob's value. It is 0.504 , which is $>0.05$ significance level it can conclude that the CR (Current Ratio) \& DAR (Debt to Asset Ratio) variables have a negative and significant effect on Profit Growth. In contrast, the ITO (Inventory Turnover) \& Sales Growth variables positively but not significantly.

\section{Coefficient of Determination}

Based on Table 1 shows that the R-Squared value of 0.3442 or $34.42 \%$, which means the variable Current Ratio, Debt to Asset Ratio, Inventory Turnover, and Sales Growth simultaneously or together can explain the Profit Growth of $34.42 \%$, other factors explain the remaining $65.58 \%$.

\section{F-Test (Simultaneous Test)}

Based on the F-Test in Table 1, the Prob value is known. (F-statistics) which is equal to $0.0007<0.05$, it can be concluded that all independent variables, namely the Current Ratio, Debt to Asset Ratio, Inventory Turnover, and Sales Growth simultaneously, have a significant effect on the Profit Growth variable.

\section{E. Moderate Regression Analysis (MRA) Test}

The moderating variable regression test in this study uses an interaction test that aims to determine whether firm size can moderate the effect of the Current Ratio, Debt to Asset Ratio, Inventory Turnover, and Sales Growth on Profit Growth. The following is a table of the results of the moderating variable analysis with the interaction test method:

$\begin{array}{llr}\text { Linear regression } & \text { Number of obs }= & 110 \\ F(8,101) & = & 6.49 \\ \text { Prob }>F & = & 0.0000 \\ \text { R-squared } & = & 0.3856 \\ \text { Root MSE } & = & .84292\end{array}$

\begin{tabular}{|c|c|c|c|c|c|c|}
\hline profitgrowth & Coef. & $\begin{array}{l}\text { Robust } \\
\text { Std. Err. }\end{array}$ & $t$ & $P>|t|$ & [ $95 \%$ Conf. & Interval] \\
\hline $\mathrm{cr}$ & .668381 & .6005916 & 1.11 & 0.268 & -.5230312 & 1.859793 \\
\hline dar & -10.2856 & 2.72232 & -3.78 & 0.000 & -15.68595 & -4.885246 \\
\hline ito & .0959798 & .2166055 & 0.44 & 0.659 & -.3337072 & .5256668 \\
\hline salesgrowth & 8.341445 & 4.788627 & 1.74 & 0.085 & -1.157903 & 17.84079 \\
\hline crxfirmsize & -.0649647 & .0463018 & -1.40 & 0.164 & -.1568151 & .0268856 \\
\hline darxfirmsize & .4552614 & .1604709 & 2.84 & 0.006 & .1369302 & .7735925 \\
\hline itoxfirmsize & -.00399906 & .0145479 & -0.27 & 0.784 & -.0328497 & .0248685 \\
\hline salesgrowthxfirmsize & -.5564437 & 3196277 & -1.74 & 0.085 & -1.190499 & .0776117 \\
\hline _cons & 2.322645 & .878027 & 2.65 & 0.009 & .5808752 & 4.064414 \\
\hline
\end{tabular}

Table 2:- Results of Regression Analysis With Moderating Variable

Based on Table 2, the significance of the moderating variable can conclude as follows: the probability value on the effect of crxfirmsize on Profit Growth is $0.164>$ significant alpha (5\% or 0.05 ). It knows that the probability value of the impact of Darfirmsize on Profit Growth is 0.006 significant alpha $(5 \%$ or 0.05$)$, and the coefficient is positive at 0.46 . Given the probability value on the effect of itoxfirmsize on Profit Growth of $0.784>$ significant 
alpha $(5 \%$ or 0.05$)$. Given the probability value on the impact of itoxfirmsize on Profit Growth of 0.085 > significant alpha (5\% or 0.05$)$.

It can conclude that firm size can strengthen the relationship between Debt to Asset Ratio to Profit Growth, but firm size is not able to moderate the effect of Current Ratio, Inventory Turnover \& Sales Growth on Profit Growth.

\section{CONCLUSION AND RECOMMENDATION}

\section{A. Conclusions}

From the research and discussion result that has carried out, conclusions can draw as follows:

$>$ The current ratio has a negative and significant effect on Profit Growth. The results of this study are in line with research conducted by AWS, Surtikanti, \& Darmansyah (2018), Simamora M. (2018), and Umobong (2015). It shows that a high Current Ratio does not necessarily positively impact the company's profit growth because of the higher the Current Ratio, the lower the Profit Growth over time. However, the high Current Ratio could be caused by the ineffectiveness of management in utilizing productive assets such as cash, inventories, and receivables, where the company holds large amounts of money, accumulated inventory in warehouses, or high trade receivables that can incur costs for the company (Hery, 2017).

$>$ Debt to Asset Ratio has a negative and significant effect on Profit Growth. The results of this study are in line with research conducted by Kariyawasam (2019), Margareth (2016), Erdoğana, Erdoğanb, \& Ömürbekc (2015), and Oktanto \& Nuryatno (2014). The negative effect of Debt to Asset Ratio on Profit Growth shows that the higher the Debt to Asset Ratio, the higher the use of debt as a source of corporate funding. Companies that have high Debt to Asset ratios indicate that most of the company's assets financed by debt. The higher of liability can have an impact on the emergence of significant financial risk, namely (1) the higher the chance that the company will not be able to pay off its debt with its assets; (2) the higher the interest expense that must be borne by the company (Hery, 2017).

$>$ Inventory Turnover has a positive but not significant effect on Profit Growth. The results of this study are in line with research conducted by Oktanto \& Nuryatno (2014), Tri Wahyuni (2017), Margareth (2016), and Simamora M. (2018). It shows the company's ineffectiveness in controlling inventory so that the funds that embedded in stock for too long turned into cash or low inventory turns. The low inventory turnover indicates the low effectiveness of inventory management, affecting the production process in increasing sales or company revenue. Oktanto \& Nuryatno (2014), in their research, stated that the effect of inventory turnover on profit growth shows that the lack of effective inventory turnover control, which indicates the low effectiveness of inventory management that can affect the production process in increasing sales or the company.

$>$ Sales Growth has a positive but not significant effect on Profit Growth. This study's results are in line with research conducted by Simamora M. (2018) and Sitohang, Fahrizal, \& Lutfi (2015). Based on research data, it can see that the sales growth generated by the company does not affect the profit growth can cause by the Cost of Sales and Expenses such as Operational Expenses and Financial Expenses that are borne by the company are relatively higher when compared with the Sales generated, so it has no effect to company profitability. Simamora M. (2018) concluded that sales growth had no significant impact on profit growth, due to the large inventory of raw materials and processed goods that were not ready for sale, resulting in reduced sales results.

$>$ Based on the interaction test results in Table 2 shows that firm size as a moderating variable can moderate the relationship between Debt to Asset Ratio with Profit Growth where the probability value of $0.006<$ significant alpha (5\% or 0.05$)$ and the coefficient value is positive of 0.46 . It shows that firm size can strengthen and a significant relationship between Debt to Asset Ratio to Profit Growth. The results of this study are in line with research conducted by Margareth (2016) which states that company size influences the relationship between Debt to Asset Ratio and Profit Growth, this shows that a large company or has a large total asset indicates better management in the management debt of a company to increase profits. In contrast, the moderating test results for the variable Current Ratio, Inventory Turnover, and Sales Growth show that the probability value is higher than significant alpha (5\% or 0.05$)$. It shows that Firm Size is not able to moderate the effect of the Current Ratio, Inventory Turnover, and Sales Growth on Profit Growth in food and beverage companies during the period 2009 to 2019. This study's results are in line with research conducted by Simamora M. (2018) and Rice (2016), which concluded that Firm Size is not a moderating variable that can strengthen/weaken the relationship between several financial ratios to Profit Growth. Profit Growth leads to the ability of managers to manage company assets. Companies with small assets, if managed better, do not rule out the possibility of obtaining enormous profit growth from companies with more substantial assets. Based on this research data, it knows that not always companies with more significant total assets will produce higher profit growth. Companies with smaller total assets do not always provide lower profit growth, the opportunity to obtain profit growth not determined by the size of the company's assets. 


\section{B. Conclusions and Recommendations}

Based on data analysis and discussion partially, Current Ratio \& Debt to Asset Ratio variables have a negative and significant effect on Profit Growth. However, Inventory Turnover \& Sales Growth variables have a positive and not significant effect on Profit Growth. Firm Size as a moderating variable can strengthen and significant the relationship of Debt to Asset Ratio to Profit Growth, but Firm Size is not able to moderate the effect of Current Ratio, Inventory Turnover, and Sales Growth on Profit Growth in food and beverage companies listed on the Stock Exchange in 2009-2019.

For subsequent researchers, it can use other variables besides Current Ratio, Debt to Asset Ratio, Inventory Turnover, and Sales Growth that can affect Profit Growth. It is recommended for subsequent researchers to use research objects in other companies on the Indonesia Stock Exchange and use the amount more samples so that the variation of data is better, giving better results. For investors, it hopes that this study's findings can use as a reference in considering factors that influence Profit Growth in making investment decisions.

\section{REFERENCES}

[1]. AWS, R. M., Surtikanti, \& Darmansyah. (2018). Determinan Pertumbuhan Laba Perusahaan Manufaktur di Bursa Efek Indonesia. Jurnal Riset Akuntansi dan Perpajakan JRAP Vol. 5, No. 2, 166 174.

[2]. Barton, L., S., Ned C. Hill, \& Sundaran, S. (1989). An Empirical Test of Stakeholder Theory Predictions of Capital Structure. Journal of the financial management Association, Vol 18(1), 36-44.

[3]. Donleavy, G. (2016). An Introduction to Accounting Theory 1st Edition. Australia: Bookboon.com.

[4]. Erdoğana, E. O., Erdoğanb, M., \& Ömürbekc, V. (2015). Evaluating the Effects of Various Financial Ratios on Company Financial Performance: Application in Borsa Đstanbul. Business and Economics Research Journal Volume 6 Number 1, 35-42.

[5]. Erlina. (2011). Metodologi Penelitian. Medan: USU Press.

[6]. Hery. (2017). Kajian Riset Akuntansi. Jakarta: PT Grasindo.

[7]. Kariyawasam, D. A. (2019). Analyzing the Impact of Financial Ratios on a Company's Financial Performance. International Journal of Management Excellence Volume 13 No.1.

[8]. Kasmir. (2015). Analisis Laporan Keuangan. Jakarta: Rajawali Pers.

[9]. Kemenperin. (2019). Kementerian Perindustrian Republik Indonesia . Diambil kembali dari https://kemenperin.go.id/artikel/20298/IndustriMakanan-dan-Minuman-Jadi-Sektor-Kampiun-

[10]. Mahardhika, R. B. (2018). Mengenal Industri Makanan dan Minuman di Era Industri 4.0. Yogyakarta: Forbil Institute.
[11]. Margareth, L. (2016). Pengaruh Pertumbuhan Rasio Keuangan Terhadap Pertumbuhan Laba Dengan Ukuran Perusahaan Dan Kepemilikan Manajerial Sebagai Variabel Moderating Pada Perusahaan Perkebunan Yang Terdaftar Di BEI Dan Bursa Malaysia Periode 2012-2014c. Medan: Universitas Sumatera Utara.

[12]. Oktanto, D., \& Nuryatno, M. (2014). Pengaruh Rasio Keuangan Terhadap Perubahan Laba Pada Perusahaan Manufaktur yang Terdaftar di Bursa Efek Indonesia Tahun 2008-2011. Danny/Muhammad Nuryatno Amin Volume. 1 Nomor. 1.

[13]. Rice, A. (2016). Analisa Faktor-Faktor Yang Mempengaruhi Pertumbuhan Laba Dengan Ukuran Perusahaan Sebagai Variabel Moderating Pada Perusahaan Manufaktur Yang Terdaftar Di Bursa Efek Indonesia. Jurnal Wira Ekonomi Mikroskil Vol. 6, No. 01.

[14]. Subramanyam, K. (2017). Analisis Laporan Keuangan. Edisi 11. Buku 1. Jakarta: Salemba Empat.

[15]. Simamora, M. (2018). Analisis Pengaruh Rasio Keuangan terhadap Pertumbuhan Laba dengan Ukuran Perusahaan sebagai Variabel Moderating pada Perusahaan Consumer Goods yang Terdaftar di Bursa Efek Indonesia. Magister Akuntansi Fakultas Ekonomi dan Bisnis. Medan: Universitas Sumatera Utara.

[16]. Sitohang, H., Fahrizal, A., \& Luthfi, M. (2015). Pengaruh Pertumbuhan Modal Dan Pertumbuhan Penjualan Terhadap Laba Bersih Pada Perusahaan Food And Beverage Yang Terdaftar Di Bursa Efek Indonesia Periode 2010-2013. Jurnal Riset Akuntansi dan Manjemen, Vol. 4 No. 1.

[17]. Tri Wahyuni, S. A. (2017). Pengaruh Quick Ratio, Debt to Equity Ratio, Inventory Turnover, dan Net Profit Margin Terhadap Pertumbuhan Laba Pada Perusahaan Manufaktur yang Terdaftar di BEI Tahun 2011 - 2015. AKUNTANSI DEWANTARA VOL. 1 NO. 2.

[18]. Umobong, A. A. (2015). Assessing the Impact of Liquidity and Profitability Ratios on Growth Profits in Pharmaceutical Firms in Nigeria. European Journal of Accounting, Auditing, and Finance Research Vol.3, No.10, pp.97-114. 